\title{
The Visioning of Policy and the Hope of Implementation: Support for Graduate Students' Teaching at a Canadian Institution
}

Carolyn Hoessler

University of Saskatchewan

Lorraine Godden

Queen's University

\begin{abstract}
Graduate students teach within the complex higher education environment of financial constraint, greater student diversity, and growing graduate enrolment (e.g., Austin, 2003). Teaching roles offer financial support and skill development while multiplying responsibilities (Price, 2008). Across the national working papers and institutional reports, policies, and websites that we analyzed, support for graduate students was linked to their roles (e.g., teaching assistants). Formal messages about responsibility varied; national documents pointed to institutions, while institutional documents pointed to departments, courses, and individual graduate students. Most supports for graduate students reported were already existing piecemeal supports with limited implementation, despite policy recommendations for broad, flexible, open-ended, and recognized programming. Future research is needed to further clarify the pathways from vision to action.
\end{abstract}

\section{Résumé}

Les étudiants diplômés enseignent dans un milieu d'éducation complexe dont les ressources financières sont en déclin, la diversité étudiante est plus importante et l'inscription aux études supérieures est croissante (p. ex., Austin, 2003). Les rôles associés à l'enseignement offrent un support financier 
et le développement d'habiletés, tout en multipliant les responsabilités (Price, 2008). L'analyse de multiples documents (travail nationaux, rapports institutionnels, politiques et sites Web) révèle que le soutien aux étudiants diplômés est lié à leurs rôles (assistant d'enseignement). Les messages formels à propos des responsabilités varient également; les documents nationaux pointent les institutions, tandis que les documents institutionnels pointent les départements, les cours et les étudiants diplômés. Le soutien le plus fréquent existait déjà, selon une mise en œuvre limitée en dépit des recommandations pour programmation plus générale, flexible, ouverte et reconnue. De nouvelles recherches sont nécessaires afin de pouvoir préciser les voies passant de la vision à l'action.

\section{Introduction}

Global trends in higher education (HE) are rapidly shifting and evolving (Wildavsky, 2010). This dynamic environment presents a number of challenges for HE institutions, including increased demands for accountability, a tightening of fiscal resources, the rise of information technologies, and increasing diversity within student cohorts (Austin, 2003; Yankelovish, 2005). Within this complex environment, graduate students attempt to successfully navigate their program of study to achieve a sense of graduateness alongside their acquisition of skills for employability (Steur, Jansen, \& Hofman, 2012). Employment as teaching assistants (TAs) can provide financial support and skill development, but adds to the juggling of responsibilities (Price, 2008) and presents new challenges, including adjusting to student-centered pedagogies demanded by the HE market place (Wright, Bergom, \& Brooks, 2011). For graduate students to be sufficiently supported in their teaching duties, the scope and quality of support matter.

Across Canada, the number of graduate students continues to increase, with Statistics Canada reporting over 165,000 studying during 2011. They are likely to have teaching assistantships during their studies; however, the literature primarily focuses on TAs in the United States (Park, 2004), the United Kingdom (Muzaka, 2009), Australia (Kift, 2003), and New Zealand (Barrington, 2001). Although provincially governed, HE in Canada is shaped by federal research funding from the Tri-Council granting agencies, including the Natural Sciences and Engineering Research Council (NSERC), as well as discussions by national bodies, including the Canadian Association for Graduate Studies (CAGS). In the absence of provincial documents, our analysis of NSERC and CAGS visioning documents, along with institutional policies and websites, tells the story of how graduate students are supported in their teaching at one Canadian institution, including the stated goals, recommendations, and existing support.

\section{Documents}

We focused our search and analysis on the national Canadian and institutional policies that describe or could shape the experiences of graduate students at one medium-size medical-doctoral university with undergraduate, graduate, and professional programs, in Ontario, Canada. Publicly available documents describing recommended or existing supports for graduate students were identified through purposeful nonsampling selection 
(Miller \& Alvarado, 2005) based on (i) a search-engine review of the institutional website for terms such as "graduate students" and "teaching," (ii) a manual search of the selected institution's institution-wide teaching, graduate studies, and student support units' websites, (iii) a search-engine search of similar terms within Canada and the province, and (iv) a manual search for national documents mentioned on higher education blogs and news reports (no provincial documents were found in the search). Given the relevancy of the original purpose, context, and intended audience of these documents to this research question, these documents were appropriate, authentic, and useful sources of data (Berg, 2004; Bowen, 2009). The resulting 10 documents, shown in Table 1, spanned sector and institutional levels to provide insight into the context shared by all graduate students and supportive individuals in this institution.

Table 1

Public Documents Analyzed in This Study

\begin{tabular}{|c|c|c|c|}
\hline Doc. \# & Name & Focus & Level \\
\hline 1 & $\begin{array}{l}\text { NSERC Working Document V2.o Professional Skills } \\
\text { Development: From Ideas to Action, February } 2007\end{array}$ & Vision & Sector-wide \\
\hline 2 & $\begin{array}{l}\text { Canadian Association for Graduate Studies - Profes- } \\
\text { sional Skills Development for Graduate Students, } \\
\text { November } 2008\end{array}$ & Vision & Sector-wide \\
\hline 3 & $\begin{array}{l}<\text { Academic Senate Committee }>\text { Sub-Committee on the } \\
\text { Training of Teaching Assistants, } 2002\end{array}$ & Report & Institution-wide \\
\hline 4 & $\begin{array}{l}\text { Teaching Assistants at <university>, May } 2005 \text { (2009 } \\
\text { revised) }\end{array}$ & Policy & Institution-wide \\
\hline 5 & Collective agreement (as of Fall 2011) & Policy & Institution-wide \\
\hline 6 & TA agreement (May 2005 version) & Form & Institution-wide \\
\hline 7 & $<$ Teaching support centre $>$ website & Resources & Institution-wide \\
\hline 8 & $\begin{array}{l}<\text { Graduate studies office }>- \text { Graduate Support Infor- } \\
\text { mation webpage }\end{array}$ & Resources & Institution-wide \\
\hline 9 & $\begin{array}{l}<\text { Academic skills support centre }>- \text { TA and Instructor } \\
\text { Resources webpage }\end{array}$ & Resources & Institution-wide \\
\hline 10 & $\begin{array}{l}<\text { Faculty support centre }>\text { New Faculty website }- \text { Re- } \\
\text { sources for TAs/Graduate Students webpage }\end{array}$ & Resources & Institution-wide \\
\hline
\end{tabular}

This study is part of a larger mixed-method investigation into support for graduate students at this institution. To maintain interviewees' anonymity, we replace the names of the university, units, and committees with generic pseudonyms (e.g., "university" in our text or <teaching support centre > in quoted text), and we do not list the URLs of websites studied when reporting illustrative quotes (Labuschagne, 2003).

At the sector level, the national conversation about graduate students historically showed limited consideration of professional skill development until 2007, when Pierre Bilodeau of the national Natural Sciences and Engineering Research Council (NSERC), a major Canadian granting agency, produced the NSERC working document V2.o Professional Skills Development: From Ideas to Action. This document identified "the importance of professional skills for new researchers including students, post-doctoral fellows 
and new faculty members [and] ... intend[ed] to propose concrete actions to promote the development of these skills" (p. 2); it also called for further discussion of these issues. In response, the Tri-Council of major Canadian research agencies, the national Society for Teaching and Learning in Higher Education (STLHE), and the Canadian Association for Graduate Studies (CAGS) held a joint workshop that resulted in nine professional skills areas, later shortened to four feasible areas in CAGS's Professional Skills Development for Graduate Students (2008). The CAGS document aimed "to identify a small core of areas of common interest, to identify gaps in the current delivery of such programs, and to begin to develop a national strategy for ensuring that all graduate students have access to at least a core set of programs" (CAGS, p. 8). This document had "the potential to be a revolutionary one" (Steele, 2009, paragraph 11) in the national landscape of graduate education. One of the four feasible areas was Teaching and Knowledge Transfer Skills, described thus:

Graduates are expected to be able to explain complex concepts related to the content, skills, and processes of their discipline . . . Graduate students planning on a variety of careers need experience in identifying the learning outcomes as well as in selecting appropriate content and delivery models. They also need experience adapting their instructional, outreach, and dissemination activities for different contexts to address different learning styles, motivations, backgrounds, and experiences. (CAGS, p. 7)

Such movement at the sector level has been mirrored in increasing program and policy growth at institutions across the country. In a quote reported by Galt (2011), Dr. Douglas Peers, past president of CAGS, said, "Over the last two or three years, [skills development] has become much more of a topic for graduate deans everywhere, so there are a lot of initiatives happening" (paragraph 8). At our selected institution, three consecutive institution-level documents set the goals, recommendations, and existing resources related to graduate students' teaching. First, a report was written by a new Sub-Committee on the Training of Teaching Assistants, after an exit survey found "dissatisfaction with Teaching Assistants among the undergraduate student population" (sub-committee report, p. 1). This sub-committee report summarized recommendations based on their review of existing supports, other institutions' practices, and three prior non-public reports within the institution. Next, a resulting senate policy formalized the report's recommendations on the processes, training, rights, and responsibilities related to teaching assistants; this received senate approval in May 2005, was revised in January 2009, and stayed in effect until the last policy, the collective agreement, was reached in 2011, following unionization. This collective agreement for graduate TAs and teaching fellows (TFs) described the processes, training, rights, and responsibilities related to both these groups but did not explicitly mention teaching or learning, unlike the previous senate policy. Both the senate policy and the collective agreement included forms for discussion between course instructors and TAs. The 2005 TA agreement form was posted as a stand-alone document on websites such as the teaching support centre, so it is treated as a separate document here. As of analysis, the collective agreement was the sole institution-wide policy in effect and still publicly available; the sub-committee report and 2005 senate policy had been retrieved while still publicly available online but are no longer posted. 
Four institution-wide websites on campus communicated existing supports for graduate students' teaching to graduate students, TAs, instructors, new faculty, and others in the institution. These websites were, specifically, the teaching support centre website (revised during our analysis), the graduate studies office webpage on resources, the academic skills support centre webpage for TAs and instructors, and the faculty recruitment centre webpage on resources for the TAs and graduate students new faculty would mentor.

\section{Analysis}

Our document analysis focused on describing the (1) stated goals, (2) existing advertised, informational, or tangible supports, and (3) recommended supports for graduate students' teaching and teaching development, defined in these 10 publicly available sector and institution-wide documents and websites. During analysis, the documents were taken at their face value and treated as formal records and resources (Hodder, 2000) that are static (Miller \& Alvarado, 2005). Using Atlas.ti (6.2.15, 1993-2012, ATLAS.ti GmbH), our analysis involved an iterative process of identifying and gathering relevant passages (content analysis) and of coding and categorizing these selected passages to uncover themes (thematic analysis; Bowen, 2009), as well as drawing on a contextual analytic approach to raise questions as to the rationale and use of these documents, particularly for consecutive institutional policies and linked websites (Miller \& Alvarado, 2005). The analysis revealed a range of stated goals, existing supports, and recommended initiatives; each set of results is outlined below. The documents analyzed in our study are considered as: (1) descriptions of existing and recommended supports; (2) stated messages providing "documentary realities" (Atkinson \& Coffey, 1997, p. 47) that communicate policy and shape experiences on the ground; and (3) actual informational supports (e.g., advice, encouragement, clarification of official responsibilities) or resource supports (e.g., slides) that graduate students may or may not access.

\section{Stated Goals}

Four components that are critical in examining the stated goals for support of graduate students' teaching were found across the documents: who was being supported; what were the benefits; who was responsible for providing support; and what were the types of support. Although all four components were not present in a single statement, most working papers, reports, and policies had pieces with each component, whereas the websites had few or none.

\section{Who Was Supported?}

The national documents (CAGS and NSERC) focused broadly on supporting all graduate students and all "new researchers" (NSERC, 2007, p. 2), encompassing undergraduate and graduate students, post-doctoral fellows, and new faculty members. In comparison, the institutional policies and forms focused specifically on TAs (as appeared in the titles of the senate policy, sub-committee report, and collective agreement)-defined, for example, by the senate policy as any students "serv[ing] under the supervision of a course supervisor in one or more of the following capacities: marker, laboratory demonstrator, tutorial leader, or other supporting role in the delivery or preparation of degree-credit 
course" (section I), or graduate students who were "teaching fellows" (collective agreement, p. 1). The institution-wide websites focused on graduate students (new faculty, teaching support centre, and academic skills webpages), TAs (new faculty and graduate studies office webpages), instructors (academic skills webpage), and all individuals who taught (teaching support centre webpage). This diversity in language suggests that stated support may have varied depending on the individual's role.

Adding further complexity, the terms "teaching assistants" and "graduate students" do not represent homogeneous groups; rather, these individuals are diverse in their responsibilities, studies, and career goals. Teaching responsibilities varied, as

TAs play different roles in different faculties and departments, . . . typically they lead tutorials or labs, mark exams and assignments and hold office hours ... they also write and present lectures, monitor course websites or listservs and supervise group projects. (sub-committee report, p. 2)

In comparison, teaching fellows had "major responsibility for planning, teaching and evaluation in an undergraduate or graduate course” (p. 3). Recognition that individual students vary was apparent, with expected support intended to be "appropriate to the needs of different student communities, according to discipline and program, taking into account level of study (Masters/PhD)" (CAGS, p. 4).

The diversity of future careers was reflected in CAGS's (2008) vision: "The target audience for professional skills development includes all graduate students and includes the range of different career paths they may follow whether in the academic, private, public, or not-for-profit sectors" (p. 4). Such diversity was seen in the university's responsibility "towards TAs with respect to their scholarly development and professional preparation for academic and non-academic careers" (senate policy, section III).

\section{What Were the Rationales and Expected Benefits?}

According to the documents, supporting graduate students' teaching benefited the individual, the institution, the sector, and society. The senate policy described teaching assistantships as

serv[ing] three valuable functions: A teaching assistantship provides teaching support to undergraduate courses; it is a significant component of financial support for a considerable number of graduate students; and for many students it is an important-in some academic disciplines even necessary-component of their professional development. (senate policy, section I)

Individual graduate students gained skills, financial assistance, and apprenticeship experience (sub-committee report), as well as "increased confidence in approaching their first job [citing Jaschik, 2008], personal reflection on managing the academic to work life transition, and engagement in a process of self-motivated learning of professional skills" (CAGS, 2008, p. 7). Institutions, departments, and individuals all benefited through

the enrichment of the professional development of Teaching Assistants and the enhancement of the apprenticeship aspect of their experience as they develop skills 
for their future endeavours, as well as the improved delivery of the academic program to undergraduate students. (sub-committee report, p. ii)

Society and the sector were viewed as benefiting from these trained graduate students, who will be the "prepar[ed] future faculty" (sub-committee report, p. 2) and the "highly skilled people needed to thrive in a knowledge-based economy and to make meaningful contributions to society, both nationally and internationally" (CAGS, p. 2). Specifically,

Canada needs a workforce which is both highly educated, and skilled to compete in the knowledge economy ... graduates need to be adaptable, flexible and to develop a broad skill set (e.g. communications, project and intellectual property management, entrepreneurship) ... Canada faces growing competition from both established and emerging economies with excellent educational systems and large numbers of qualified people. (NSERC, p. 2)

Support thus was portrayed as providing a threefold benefit across the individual, institution, and sector/society.

\section{Who Was Responsible?}

Yet who was responsible for providing such intended support to achieve such benefits? The sector-level CAGS and NSERC documents placed responsibility on institutions: "the university is responsible for providing graduate students with the best possible preparation for their future roles whether within academia or in other sectors. This responsibility extends to developing professional skills" (CAGS, 2008, p. 4). The exact approach was left to individual institutions, as "[u]ltimately, each university makes the final determination, within its own context, of how to select, resource, and implement the development and delivery of individual professional skills programs" (CAGS, 2008, p. 8). This freedom may reflect the fiscal challenges institutions face:

The challenges and opportunities inherent in [universities'] dual mandate of research/inquiry and teaching/learning ... [are] further exacerbated by the funding structures of post-secondary education (PSE), partially due to substantial declines over the past several years in funding for teaching alongside much needed increases in funding for research. (NSERC, 2007, p. 3)

This "reality of resource limitations at all academic institutions" (CAGS, 2008, p. 1) also suggests a potential role for the sector level to provide for such resources, particularly provinces, as the "federal granting agencies have been quieter towards identifying professional skill training as a priority, primarily because of the training component which in the Canadian landscape is seen as closely associated with education, a responsibility of provincial governments" (NSERC, 2007, p. 3). In spite of the lack of a national-level strategy determining levels of expected support for graduate students, this NSERC working paper called on several federal bodies to "join forces in developing a statement of principle on professional skills training” (p. 4).

Beyond finding resources and identifying skill areas, institutions face the challenges of: "Avoiding extending the length of graduate programs, Being explicit in the learning 
objectives . . B Balancing voluntary with compulsory programs, Identifying the unit or units on campus responsible for development and delivery of programs" (CAGS, p. 7-8). The studied institution's documents ascribed responsibility primarily to departments, courses, and individuals instead of institution-wide units or committees: "TA development and training is primarily a departmental responsibility at [institution]" (sub-committee report, p. 3). Agreement forms (senate policy, collective agreement) and mid-point reviews (collective agreement) tasked course instructors or supervisors with discussing hours and responsibilities, giving feedback (old TA agreement form and the teaching fellow form), and providing training (in a section of the old TA agreement form, a checkbox on the new TA form, and the teaching fellow form).

At the individual level, graduate students were responsible for "mak[ing] yourself aware of [these supports] . . . as early as possible" (graduate studies webpage); further, when offered "work exceeding the maximum allowable hours of work, it is the graduate student's responsibility to decline" (Collective Agreement, p. 14). In conclusion, the division of responsibilities was: offering advocacy and resources at the sector level, providing expected support at the institutional and department levels, communicating at the course level, and striving for awareness and fairness at the individual level.

\section{What Were the Existing Types of Support?}

Stated supports for graduate students' teaching varied: sector-level documents described skill development opportunities, while institutional documents listed advertised, informational, or tangible supports. Nationally, CAGS (2008) focused on the development of professional "skills that are complementary to disciplinary knowledge and that will enhance the graduate's ability to be successful in the transition from academic to work life" (p. 3). Some financial support was promised nationally through "programs . .. for students and [post-doctoral fellows] to further develop those skills through direct industry interactions" (NSERC, 2007, p. 5).

The 2002 sub-committee report encouraged a wider-range of institutional support: "Preparation for a TAship should include, but not be restricted to, practical hands-on training for specific duties. It must also include mentoring, monitoring, and other forms of support for the continuing development of the TA's instructional abilities" (p. 5). In addition to sector-level funding, noted supports for graduate students' teaching included institution-wide informational resources on teaching support centre programming and resources, rights, responsibilities, and feedback; departmental training; course-level discussions; support from instructors and peers; and individual variability. Each of which is explored separately here.

\section{Institution-Wide Resources}

The institution contained several units on campus that supported graduate students directly or indirectly with programming and informational resources, including a teaching support centre, an academic skills support centre, graduate studies, and resources for supervisors and instructors who were new faculty (see Figure 1). When analyzed, the webpages of these units and the institutional policies described supports (e.g., advertised programming and services) and acted as support in the form of informational guidance (e.g., handbooks) or tangible artifacts (e.g., feedback templates, slides). 


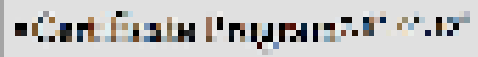

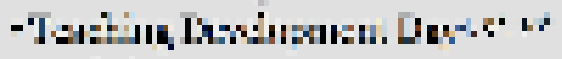

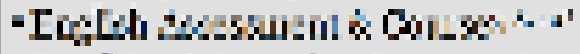

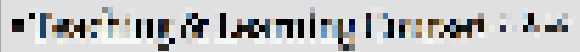

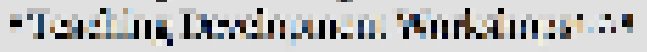

- I. hing:- "

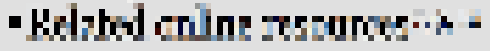

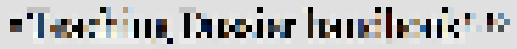

- Th Houltodr

- Constidon \& 1

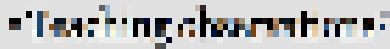

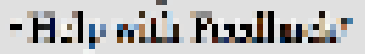

Thuthing Sinpert dentre

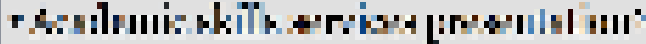

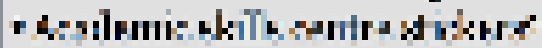

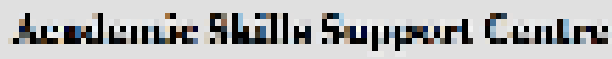

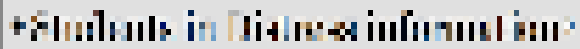

Diher mantom sertions

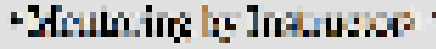

- Hem - dris wirs -

r Fulforit'

40uspos

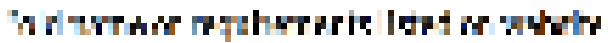

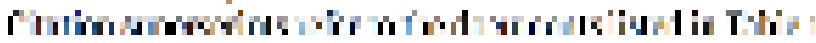

Figure 1. Existing Resources

Most of the supports described in the sub-committee report and senate policy were stated to be provided by the teaching support centre; they represented the totality of those listed on the new faculty's TA/graduate students webpage, and the majority of teachingrelated programming and resources on the graduate studies and academic skills support centre webpages (shown in Figure 1). Specifically, the teaching support centre's website described a course on teaching and learning for all graduate students, a course on communication in teaching for international students, a certificate program, a teaching development day filled with workshops in September, a workshop series during fall and winter terms, a resource library, and consultations (e.g., teaching observations, resource recommendations, curriculum or course planning, and help with feedback collection and interpretation). The advertising value of these websites, however, was compromised (when examined on January 2, 2012) by the inclusion of broken links and outdated names and descriptions (see the asterisks in Figure 1). For example, the annual day was mislabeled (new faculty webpage, academic skills support centre webpage), and links to the teaching support centre were broken (academic skills support centre, graduate studies office, and new faculty webpages). Such misinformation and broken links may create challenges for those seeking support.

Informational guidance was offered on some webpages and in some policies, including the teaching support centre webpages' online topic-specific information, a teaching dossier handbook, and a TA handbook. Institutional policies outlined the responsibilities and rights of graduate students as TAs (senate policy and collective agreement) and teaching fellows (collective agreement). The 2005 senate policy was the first institutionwide document to state rights and responsibilities for TAs as employees, including role 
expectations, a protocol for resolving disputes, and policies around ethics, equity, safety, health, discrimination, and harassment. The section on work environment covered workload, remuneration, leaves of absence, religious holidays, assistantship allocations, and the TA agreement form. To an even greater extent, the collective agreement that followed focused on employee rights and responsibilities; for example, it communicated expectations regarding work hours and other activities, including a maximum of "an average of ten (10) hours per week" (p. 21) and not "more than eight (8) scheduled hours per day" (p. 21), excluding field trips.

Few tangible artifacts that graduate students could download and use were found. The academic skills support centre webpage offered PowerPoint slides that graduate teaching assistants and instructors could use in their teaching to show what services are available to their students. These slides complemented the checkbox referral stickers noted as available, to further guide their students to such services rather than strain their own limited teaching time. Tangible agreement forms were available for graduate students to seek and receive feedback-an "essential component of effective TA training programs" (sub-committee report, p. 5) -in addition to the described consultations. Evaluation of teaching was listed on the old TA form (senate policy) and the new TF form (collective agreement) but not on the new TA form or in the collective agreement itself. The original TA agreement form identified three sources of feedback (students, supervisor-recommended in the senate policy-and other) when asking instructors to "[o]utline clearly how the TA's performance will be assessed ... (i.e. Will students fill out end-of-term questionnaires? Will the teaching supervisor do in-class observations and offer feedback to the TA? Will obtaining feedback be the responsibility of the TA?)."

The new TF form specified three options for collecting feedback: "a) Participating in formal course evaluations ... b) Actively responding to student feedback on an ongoing basis ... c) Seeking input and support from colleagues or university resources as appropriate" (collective agreement, p. 37). Individual graduate students could also take the initiative to collect feedback from students through sample evaluation forms created by the teaching support centre, although the senate policy stated that "[o]nce a university-wide evaluation system has been developed, all TAs should be assessed accordingly" (section XI). However, such sample feedback forms were not found within the policies or on any of the websites, including the teaching support centre's, when examined December-January 2012 after the new collective agreement was signed and replaced the senate policy.

\section{Departmental Training}

In addition to institutional resources, departments were key providers of the stated support, as the 1993 report to the Dean of Graduate Studies noted both "the importance of the role of the <teaching support centre $>$... [and] further emphasiz[ed] the significant role that must be played by individual departments in ensuring that effective training of TAs occurs consistently" (sub-committee report, p. 2). Departments offered a variety of TA programming, including "annual orientation and training sessions ... ongoing seminars on teaching, and courses on how to support learning in their respective disciplines" (p. 3). Such training could be strengthened through collaboration with the teaching support centre, which reportedly provided "a TA Training Manual and an annual workshop for faculty who are responsible for TA training and development in their departments" (p. 3). However, neither were listed on the websites in 2012. 
Departments were previously required to provide three hours of mandatory training, as recommended in the 2002 sub-committee report, described in the original TA form's "Training and Development" section, and enshrined in the 2005 senate policy statement that "all new TAs must participate in a three-hour mandatory training session organized by their units before taking up their assigned duties, except where there is a process in place providing ongoing training throughout the term" (section IX). While the collective agreement that followed specified that "[a]ll Employer-required training shall be compensated at the TA's regular rate of pay" (p. 22), the agreement did not require a minimum number of training hours, and the new TA form listed "employer-required training" as an option in the "other duties" section, along with "attending lectures" and "preparation time" (p. 35). Responsibility for paying graduate students for training-as for payment in general-fell on departments (graduate studies office webpage).

\section{Course-Level Discussions}

The original senate policy TA form and later the collective agreement TA and TF forms provided a framework for conversations about responsibilities, feedback, and training. The original TA agreement from the senate policy listed training, feedback, and 19 possible responsibilities, grouped under the headings "Contact with Students," "Contact with Supervisor," "Marking and Grading," and "Other Duties" (e.g., "preparation time"). All sections had an "other" checkbox, space for expected hours, and notes. With the new collective agreement, duties and hours were specified either by the course instructor completing a Teaching Assistant Form (TA form) or by a departmental administrator completing a Teaching Fellow Form (TF form) "by the end of the second week of the Academic Term" (p. 22) and providing a copy to the TA or TF. Discussions midway through the contract were required "for the purpose of conducting a review of the TA's assigned activities ... [to] ensure that the TA's hours of work, as set out in her/his TAF, continue to be appropriate" (p. 21). Further revisions required subsequent meetings.

\section{Support From Instructors and Peers}

Instructors and peers further expected to support graduate students' teaching. Instructors were seen to "play a major role in motivating TAs and assisting them in their professional development" (sub-committee report, p. 5) and should "be recognized" (p. 5). Peers, as experienced TAs, could provide mentorship by being "invited to take responsibility for supervising and mentoring their peers" (sub-committee report, p. 5). Involving peers in training programs also "ensures that initiatives are relevant to TA interests, needs and stage of development" (sub-committee report, p. 5). The potential for such support was not further discussed.

\section{Individual Variability}

Although such supports were described as existing, graduate students' individual experiences varied drastically across and within institutions, according to the 2002 subcommittee report:

Although there are many training opportunities for TAs at [institution], there is 
currently tremendous variation in the teaching development experiences of individual TAs. Many TAs receive absolutely no preparation and minimal support for their duties; others participate in specialized TA training workshops offered by their departments and/or the <teaching support centre $>, \ldots<$ teaching and learning courses $>$, or other discipline-specific credit courses ... designed to prepare them for a future life as a university professor as well as their immediate TA duties. (p. 4)

Across the sector, training "formats var[ied] widely, ranging from a 2-hour workshop, to a 2- or 3-day orientation program, to a series of seminars offered over a full term" (subcommittee report, p. 4), and only a few offered teaching-related certificate programs, credit courses, and international TA training. Thus, while support was described or was provided as information or tangible artifacts at all levels, individual experiences varied.

\section{What Was Further Recommended?}

Most of the documents focused exclusively on noting existing supports or anticipated supports that were to be implemented upon approval of the senate policy or collective agreement. Without specifying the types of support, the CAGS document did recommend principles, including: "Professional skills development will be more successful and more efficient if it is formally recognized by the institution"; and such "[p]rograms ... should be experiential and open ended in nature" (p. 4). Similar qualities were suggested by the sub-committee report, which described effective support as:

Broad: "Preparation for a TAship should include, but not be restricted to, practical hands-on training for specific duties. It must also include mentoring and monitoring and other forms of support for the continuing development of the TA's instructional abilities." (sub-committee report, p. 5)

Disciplinary: "TA programs must include a significant degree of training at the disciplinary level to create a close link to the respective scholarship and values in a given area of study and to reflect the discipline-specific culture of teaching and learning." (sub-committee report, p. 5)

Flexible: Support "must take into consideration the needs of the students who serve as TAs, such as ... the long-term demands placed on many graduate TAs who have to prepare for their future roles as instructors in higher education. Furthermore, training and development programs must meet the unique needs of international student TAs. Therefore, the kind of work assigned to TAs should reflect the learning needs of the students serving as TAs as well as the instructional staffing requirements of academic programs." (sub-committee report, p. 4)

Well-Constructed: "While a minimum of mandatory preparation is desirable and necessary ... [i]t is important to offer meaningful incentives and to construct TA training programs that can facilitate ... many students' intrinsic motivation . .. TAs deserve and benefit from programs that challenge and encourage them to experiment, to reflect ..., to be creative, to care about teaching, to share ideas and to discover the importance and value of their work." (sub-committee report, p. 5) 
Thus, support was recommended to be open-ended, recognized, broad, disciplinary, flexible, and motivating; however, descriptions appearing in later documents suggest existing and implemented supports were still piecemeal. In addition, there was limited evidence of implementation of the nine recommended supports of the sub-committee report across the later documents, as shown in Figure 2.

Sub-committee report Recommendation 2002
Senate Policy 2005
Collective Agreement 2011
Websites 2012

\title{
1. Departments review support
}

\begin{abstract}
"Departments ... review their current TA training practices with the goal of creating comprehensive approaches to TA development (including workshops for beginning TAs, support for more experienced TAs and self-directed programs for TAs who want to improve their teaching)...[how] they select, mentor, and assess their TAs, formally define their roles and responsibilities and facilitate the resolution of disputes" (p.6)
\end{abstract}

\section{Departmental designate, annual report}

"Departments designate an individual who has a special interest in TA training and development and who will be responsible for (a) assessing existing TA practices, and (b) providing a brief annual report to the Department Head (with copies to the respective Faculty Dean, the Dean of Graduate Studies...<teaching support centre $>$ )" (p. 6)

\section{Institution-wide inventory of TA training to be complied by teaching support centre}

"the <teaching support centre> develop a report form and distribute it to Departments... on an annual basis together with additional information about programs, workshops and other training opportunities provided by the <centre who $>$ keep an inventory of the TA training efforts reported by each academic unit and advise the <VP-Academic $>$ " (p.6)

\section{Consider recognizing faculty}

"Conside[r]...having Internal Academic Reviews contain a section on TA training and development and faculty members be encouraged to include their TA training and development activities in their annual reports" (p. 7)

\section{Contracts and minimum training}

"all TAs receive contracts specifying their duties and training requirements, and that all new TAs participate in a mandatory training session of at least three (3) hours before taking up their assigned duties and that Departments ... organize these sessions with assistance from the $<$ teaching support centre >" (p. 7)

\section{Contracts for TAs with 3 hours minimum training} for new TAs report" (Section 'assessing'

\section{University-wide certificate program in teaching by teaching support centre}

"<university > implement an optional university-wide $<$ program $>$, with a

Certificate of Completion provided to successful participants by the $<$ teaching support centre>" (p. 7)

\section{Testing for international graduate students}

a mandatory diagnostic assessment of ESL oral proficiency be developed. That all new graduate students who were required to obtain satisfactory results in an English language proficiency test for admission be required to undertake this supplementary assessment before they begin their work as TAs. (p. 8)

\section{Course for international graduate students}

new term-length course ... be mandatory for all graduate students who were required to obtain satisfactory results in an English language proficiency test for admission and who have failed the diagnostic test of ESL oral proficiency" (p. 8)

\section{TA development coordinator}

"hired with the mandate to support departmental training programs, to act as a resource person on TA development for the <institution $>$ and to coordinate < certificate> $>$ (p. 8)

Contracts for TAs and TFs. All training paid but no minimum

Figure 2. Recommended Resources 


\section{Summary}

The story of supporting graduate students' teaching, as told by these documents, is one of programming and other formally offered supports for graduate students' practical training. The goals for success in their immediate tasks as teaching assistants and in their future careers were noted by sector-level statements and the 2002 sub-committee report, with brief mentions in the senate policy, but not in the recent collective agreement. Most documents that described existing or recommended supports were formal, offered primarily by the institution-wide teaching support centre and departmental training. Recognition of graduate students' teaching excellence-through awards-occurred at the departmental level (graduate studies office webpage) or at the department, institution, and sector levels (teaching support centre website). Informal, just-in-time conversational support was not mentioned in these documents, beyond the suggestion for the institution to formalize instructor and peer mentorship (sub-committee report, 2002).

Communication about expectations, responsibilities, and rights was expected to occur through having institution-level policies available and agreement forms completed for each teaching assistantship and teaching fellowship. Websites, if updated with working links and accurate descriptions, could provide further communication about available services, programming, and resources. Informational networks-based on designated individuals in departments and on annual reports, as recommended in the 2002 subcommittee report-were enacted as part of the later senate policy, while the similarly recommended inventory and TA coordinator position did not appear elsewhere in the documents. These documents thus told a story of clear policies on TAs' rights and responsibilities in teaching roles, a variety of formal departmental training and formal programs, services, or informational resources across campus.

Policies and resources across the levels interacted in ways that could increase anticipated support for graduate students' teaching, such as prior institution-level policies (e.g., mandating three hours of training) enacted at the departmental level. However, even when policies encouraged supports, gaps occurred in implementation, as captured in these documents. For example, feedback was recommended in the sub-committee report but without an institution-wide evaluation process being put in place for TAs, and feedback was listed on the original TA form (senate policy) but not the current TA form (collective agreement). When such gaps occurred, opportunities and access to support were left to the individual.

\section{Implications of This Study}

The documents analyzed in our study described existing and recommended supports, conveyed messages that matter in the way policy generally shapes experiences on the ground (e.g., Cheung, Mirzaei, \& Leeder, 2010; Prior, 2003), and also may themselves be informational supports (e.g., providing advice, encouragement, and/or clarification of official responsibilities) or tangible artifacts of support (e.g., slides). Our study revealed how concurrent documents showed inconsistencies in descriptions of what supports exist, and included broken links and outdated names that may impede communication. We remain curious about how graduate students perceive these breaks in communication and how such discordance impact upon the actual level of support provided. Additionally, 
the extent to which the disconnect portrayed in these documents is embodied in organizational functioning and communication between groups remains unclear and requires further investigation. Beyond inconsistencies between policy and actual experience found in prior policy implementation research (e.g., Coburn, 2001; Spillane, Diamond, Burch, Hallet, Jita, \& Zoltners, 2002; Weick, 1995), this study demonstrates that gaps occur between intended policy statements-let alone between policy and actual experience. With gaps in the intended policy and formal messages, there is the potential for even wider diversity in interpretation and thus gaps between policy and implementation. While analysis of documents and websites from disciplinary units or from individual courses could have provided insight into how institutional policies were interpreted and enacted locally, this complexity was beyond the scope of this study due to the limited access to documents located in online learning communities or secure areas.

In spite of this limitation, our study has revealed how some recommendations are embedded in or described as enacted across consecutive documents and others are not. Clearly, the implementation of support for graduate students' teaching involves much more than a simple execution of previously-arrived-at policy decisions portrayed in institutional documents (Howlett, Ramesh, \& Perl, 2009). Prior (2003) considers that every document produced is packed with assumptions, concepts, and ideas that are reflected by the document's producers and recipients, and by the events and people reported upon within the documents. Within this complexity, documents are interpreted and enacted into practice. The gaps identified in our study's findings are not altogether unexpected, as the policy implementation process is "fraught with challenges and risks of failure" (Howlett et al., 2009, p. 173). However, as we consider these gaps, we are left wondering: How do institutional and local contexts, including missions, organizational learning processes, and resources, influence which recommendations are enacted and how? We would suggest that there is a need for further research (1) to investigate the contextual factors that may influence how policy documents become interpreted and enacted into working practice, and (2) to identify the full range of supports available to graduate TAs, in addition to those mentioned in these documents, at this institution and beyond. Undertaking such research would support the notion that policy implementation can only be meaningfully understood and fully evaluated though examination of the whole policy subsystem-including the policies themselves, the policy actors interpreting and acting upon those policies, and the contextual constraints within which they operate (Bressers \& O’Toole, 1998; Howlett, Ramesh, \& Perl, 2009).

The findings of our investigation, and the acknowledged limitations, prompt us to call for further research in this crucial area. The Teaching Assistant and Graduate Student Advancement (TAGSA) organization, a special interest group within the STLHE, produced a report in 2011 that examined TA professional development in Canada. Though the report provided examples of good practice, the author acknowledged that the report is merely a snapshot, not representative of the extensive work being undertaken in each university across Canada. In addition, a report prepared by Rose (2012) for the Social Sciences and Humanities Research Council of Canada (SSHRC) surveyed the graduate student professional development programming available to support graduates students' academic and broader transferable skills. Though both reports provide some information on the types of support available to graduate students, they are concentrated on institution-wide pro- 
gramming and may miss additional supportive policies. Given the global pressures on higher education institutions and their student bodies, it is imperative that the levels of support needed by diverse TA communities be fully understood for policy responses to be appropriately implemented.

We suggest that a way to understand the gaps in the policy implementation process and the variations in enacted practice should be examined within the organizational complexities wherein they operate. Land (2001) has provided a useful model with which to begin such an examination. Land's model of academic development (p. 9) links the "concepts of change" (i.e., the global pressures on higher education institutions and their student bodies) with the "different orientations that developers consider appropriate to their strategic terrain" (p. 4). The strength of applying Land's model as one approach to understand policy responses to levels of support required by diverse TA communities is in its multifaceted, interrelated, overlapping, and dynamic perspective, which allows for consideration of the entire context within which policy implementation takes place. An examination of how support for graduate students' teaching is implemented could address the question: How do institutional and local contexts, including their missions, organizational learning, and resources, influence how and which recommendations are enacted?

Thus, we conclude that there appear to be gaps in implementing recommended supports for graduate students, increasing the need to understand both these individuals' current support status and how improved support could be better implemented. In addition to research on the process of implementing graduate student support policies, future effort is needed to undertake a pan-Canadian examination of existing supports for graduate student development and teaching. Such knowledge would inform and ground conversations at national, provincial, and institutional levels, which could then envision policies to support graduate students at their core and engender the hope of subsequent successful implementation.

\section{References}

Atkinson, P., \& Coffey, A. (1997). Analysing documentary realities. In D. Silverman (Ed.) Qualitative research: Theory, method, practice (pp. 44-62). London, UK: Sage.

Austin, A. E. (2003). Creating a bridge to the future: Preparing a new faculty to face changing expectations in a shifting context. The Review of Higher Education, 26(2), 119144 .

Barrington, E. (2001). Encouraging professional training of graduate teaching assistants. Journal of Graduate Teaching Assistant Development, 8, 107-113.

Berg, B. L. (2004). Qualitative research methods for the social sciences. Boston, MA: Pearson.

Bowen, G. A. (2009). Document analysis as a qualitative research method. Qualitative Research Journal, 9, 22-40. doi: 10.3316/QRJ0902027

Bressers, H. T. A., \& O'Toole, L. J. (1998). The selection of policy instruments: A network-based perspective. Journal of Public Policy, 18(3), 213-239. 
Canadian Association for Graduate Studies [CAGS]. (November 2008). Professional skills development for graduate students. Retrieved from http://www.cags.ca/media/ docs/cags-publication/Prof\%20Skills\%20Dev\%20for\%20Grad\%20Stud\%20\%20 Final\%2008\%2011\%2005.pdf

Cheung, K. K., Mirzaei, M., \& Leeder, S. (2010). Health policy analysis: A tool to evaluate in policy documents the alignment between policy statements and intended outcomes. Australian Health Review, 34(4), 405-413.

Coburn, C. E. (2001). Collective sensemaking about reading: How teachers mediate reading policy in their professional communities. Educational Evaluation and Policy Analysis, 23(2), 145-170.

Galt, V. (2011). Professional development for grad students. University Affairs. Retrieved from www.universityaffairs.ca/professional-development-for-grad-students. aspx

Hodder, I. (2000). The interpretation of documents and material culture. In N. K. Denzin \& Y. S. Lincoln (Eds.), Handbook of qualitative research (pp. 703-715). Thousand Oaks, CA: Sage.

Howlett, M., Ramesh, M., \& Perl, A. (2009). Studying public policy: Policy cycles and policy subsystems (3rd ed.). Don Mills, ON: Oxford University Press.

Jaschik, S. (2008, July 11). Confidence gap for new profs. Inside Higher Education. Retrieved from http://www.insidehighered.com/news/2008/07/11/newfac

Kift, S. (March 2003). Assuring quality in the casualisation of teaching, learning and assessment: Towards best practice for the first-year experience. ultiBASE. Retrieved from http://ultibase.rmit.edu.au/Articles/marcho3/kift1.pdf

Labuschagne, A. (2003). Qualitative research: Airy fairy or fundamental? The Qualitative Report, 8(1), Article 7. Retrieved from http://www.nova.edu/ssss/QR/QR81/labuschagne.html

Land, R. (2001). Agency, context and change in academic development. International Journal for Academic Development, 6(1), 4-20.

Miller, F. A., \& Alvarado, K. (2005). Incorporating documents into qualitative nursing research. Journal of Nursing Scholarship, 37, 348-353.

Muzaka, V. (2009). The niche of graduate teaching assistants (GTAs): Perceptions and reflections. Teaching in Higher Education, 14, 1-12. doi: 10.1080/13562510802602400

National Science and Engineering Research Council [NSERC]. (2012). Collaborative Research and Training Experience Program. Retrieved from http://www.nserc-crsng. gc.ca/Professors-Professeurs/grants-subs/CREATE-FONCER_eng.asp

Park, C. (2004). The graduate teaching assistant (GTA): Lessons from North American experience. Teaching in Higher Education, 9, 349-361. doi: $10.1080 / 1356251042000216660$

Price, S. (2008). GUIDE: Graduates united in dialogue for excellence. The Journal of Continuing Education in Nursing, 39(7), 314-318. 
Prior, L. (2003). Using documents in social research. London: Sage.

Rose, M. (2012). Graduate student professional development: A survey with recommendations. Social Sciences and Humanities Research Council of Canada.

Spillane, J. P., Diamond, J. B., Burch, P., Hallett, T., Jita, L., \& Zoltners, J. (2002). Managing in the middle: School leaders and the enactment of accountability policy. Educational Policy, 16(5), 731-762.

Statistics Canada. (2011). Table 1: University enrolment by registration status, program level and gender. Retrieved from http://www.statcan.gc.ca/dailyquotidien/090713/to90713a1-eng.htm

Steele, C. (2009, April 13). Professional skills for graduate students. University Affairs Blog: Career Sense [Web log message]. Retrieved from http://www.universityaffairs.ca/ career-sense/professional-skills-for-graduate-students

Steur, J. M., Jansen, E. P. W. A., \& Hofman, W.H.A. (2012). Graduateness: An empirical examination of the formative function of university education. Higher Education, 64(6), 861-874.

Weick, K. E., (1995). Sensemaking in organizations. Thousand Oaks, CA: Sage.

Wildavsky, B. (2010). University globalization is here to stay. Chronicle of Higher Education, 57(1), 44-46.

Wright, M.C., Bergom, I., \& Brooks, M. (2011). The role of teaching assistants in studentcentered learning: Benefits, costs, and negotiations. Innovative Higher Education, 36(5), 331-342.

Yankelovish, D. (2005). Ferment and change: Higher education in 2015. Chronicle of Higher Education, 52(14), B6-B9.

\section{Acknowledgement}

This research was supported through a Doctoral Fellowship from the Social Sciences and Humanities Research Council of Canada (SSHRC).

\section{Contact Information}

Carolyn Hoessler

The Gwenna Moss Centre for Teaching Effectiveness

University of Saskatchewan

carolyn.hoessler@usask.ca

Carolyn Hoessler's research encompasses contextual, interpersonal, and motivational influences shaping educational and professional development experiences in higher education. She draws on her experience as an educational developer, mixed-method researcher, dessert baker, and Program and Curriculum Development Specialist at The Gwenna Moss Centre for Teaching Effectiveness, University of Saskatchewan. 
Lorraine Godden's research includes career education, professional development of educators, and the role of mentoring as both support and scaffold for successful professional and leadership development. Lorraine draws on her experience of working in the profit and non-profit sectors, as an educational manager, an eternal snow shoveller, and-more recently-from her qualitative research with at-risk youth, trainee teachers, and graduate students. Lorraine's doctoral work examines the intersection between educators, policy, and curriculum documents in the policy implementation process. 